\title{
TEXTURAL AND GENETIC CLASSIFICATION SCHEMES FOR KIMBERLITES: A NEW PERSPECTIVE.
}

\author{
Field, $\mathrm{M}^{1}$. and Scott Smith, B.H. ${ }^{2}$
}

1. Dept. De Beers Consolidated Mines, Kimberley Mines. P.O. Box 10191, Beaconsfield. 8315, South Africa.

2. Scott Smith Petrology Inc., 2555 Edgemont Boulevard. North Vancouver. B.C. V7R 2M9., Canada

Textural variations in kimberlites result primarily from near surface emplacement processes and to understand these requires a workable classification. In 1979 a landmark advance in rationalizing previous textural terminology for kimberlites was made by Clement and Skinner (1979 cited in 1985) when they proposed the first widely accepted, and now well tested, textural-genetic classification scheme. The main shortcoming of the Clement and Skinner classification is the fact that it is genetic and an initial decision regarding facies has to be taken before a rock can be classified. Recent discoveries, particularly in Canada, have highlighted this shortcoming. The reverse logic should be applied. Observations should first lead to a non-genetic descriptive classification that is then used to arrive at a genetic classification when possible. Based on this concept a new textural classification scheme for kimberlites is proposed here (Fig. 1). This scheme is based on the fundamentals of Clement and Skinner (1985). The new classification scheme is based on five descriptive textural categories namely: juvenile magma texture, structure, clast/grain size, xenolith/autolith content and type and cognate olivine content (listed in order of diagnostic importance).

Juvenile magma texture: The introduction of this descriptive category is the main modification to the previous classification. This category deals with the textural products of the kimberlite magma, which is the fundamental feature that reflects the mode of emplacement. The initial sub-division distinguishes between rocks derived from either coherent or disrupted molten magma. Those derived from coherent magmas are referred to as magmatic kimberlites and those derived from disrupted magmas are described using a new term magmaclastic. Magmatic rocks must have textural features displaying crystallisation from a non-disrupted magma. Most magmatic kimberlites have a wellcrystallised groundmass that is easily identified. Magmatic kimberlites are further sub-divided into uniform and segregationary textured varieties after Clement and Skinner (1985). Magmaclastic rocks are diverse. There are three different types of juvenile magma clasts: globular-segregations, pelletal lapilli, and pyroclastic lapilli which are set in a contrasting inter-clast matrix. The identification of the different types of magma clasts is difficult. The matrix is either of magmatic or non-magmatic origin. Prior to emplacement, kimberlites contain large quantities of cognate olivine crystals that can become separated from the liquid magma during disruption. Rocks formed by this process are catered for as a sub-type of "magmaclastic" even though they do not strictly contain magma clasts. However, they derive from the same magma disruption process.

Structure: It is valid to use as a descriptor any micro- to megascopic feature that reflects the structure of the rock. These features are essential to the successful interpretation of many rocks. The possibilities are almost endless, so terms are not prescribed here, but the following examples serve to demonstrate the concept; monotonous or massive, inhomogeneous, flow-banded, bedded, graded, sorted and degree of packing.

Grain/clast size classification: This classification can be used either for magma clasts or olivines but not to describe the xenoliths or autoliths (see below). This classification was devised to allow correlation with kimberlite grain size and other volcanological and sedimentological terminology. 
Xenolith and Autoliths: With respect to abundance, the term breccia $(\mathrm{KB})$ and microbreccia $(\mathrm{KmB})$ are applied as shown in Fig. 1. The next sub-division is by rock type (see Fig. 1). Xenocrysts derived from all the xenolith types also occur. The olivine xenocrysts derived from mantle xenoliths are catered for in a separate category (see below).

Olivine Content: Olivine, an essential mineral in kimberlite, is placed into a separate category. The use of the terms macrocrystic, sparsely macrocrystic and phenocrystic are shown in Fig. 1 . The term phenocrystic is a new term coined to replace aphanitic and is used in all textural types.

\section{Naming and interpreting rocks}

Textural classification: The textural classification (Fig. 1) is constructed in such a way to illustrate that the terms are mainly descriptive. The naming of a rock can derive from any level of detail the observations allow, and there is no prescribed format. Terms can be omitted if they are implied within other descriptors. All of the observed features on which the descriptive terminology is based can be used to obtain a genetic interpretation (Figs. 1\&2). An interpretation is not essential, as it often cannot be achieved due to factors such as the lack of diagnostic features or weathering. Proposed interpretations will have varying degrees of confidence. Some examples are listed below:

Flow-banded, macrocrystic, magmatic kimberlite with a uniform textured groundmass which is interpreted as HK (Plate 1a of Clement and Skinner, 1985).

Monotonous, matrix-supported, pelletal-magmaclastic, macrocrystic kimberlite lithic breccia with magmatic inter-clast matrix which is interpreted as TKB (Clement and Skinner, 1985 plate 2c).

Bedded, graded, clast supported, magmaclastic VF-FK with non-magmatic inter-clast matrix interpreted as post-eruptive RVK (epiclastic; Clement and Skinner, 1985 plate 2d).

Pipe zone: As a result of this classification scheme, the description of the pipe infilling is distinctly separate from concepts relating to pipe shapes and zones. Kimberlite pipe is used as a non-genetic term to describe a body that is not sheet-like in shape. The pipe-zone concept is a description of the shape and origin of different parts of the pipe (Fig. 2). Simple descriptors such as steep, shallow or irregular can be used to describe all or part of the pipe. Only if the pipe can be shown to have formed by the fluidisation processes of the southern African kimberlite model (Field and Scott Smith, this volume) can the term diatreme zone be applied. The term kimberlite diatreme becomes a very specific term.

Facies classification: Previous use of pipe-zone and rock-type facies concepts are essentially correct, but they need to be more clearly separated (Fig. 2). Textural types of kimberlite are typical of, but not exclusive to, certain pipe zones. Only if the main infill of a pipe zone is characteristic of that zone should the terms crater-facies, diatreme-facies and hypabyssal-facies be applied. For example a steep sided pipe infilled with VK should not be termed a diatreme or the infill diatremefacies.

\section{Reference}

Clement, C.R., and Skinner, E.M.W., 1985, A textural-genetic classification of kimberlites. Trans. geol. Soc. S. Africa 88, 403-409. 


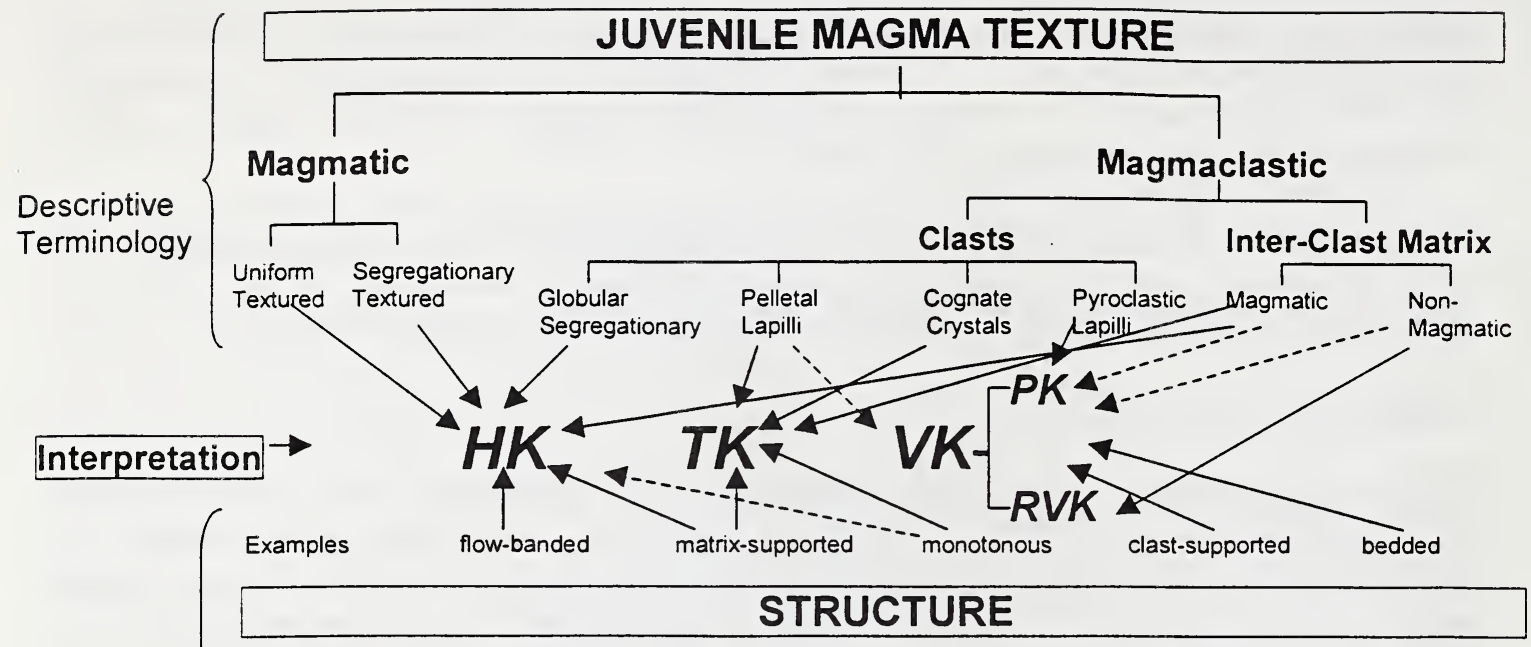

Descriptive Terminology

\begin{tabular}{|c|c|c|c|c|c|c|c|}
\hline \multirow{2}{*}{\multicolumn{2}{|c|}{$\frac{\text { Cognate Olivine }}{\text { Content }}$}} & \multirow{2}{*}{\multicolumn{4}{|c|}{$\frac{\text { Magmaclast / Olivine }}{\text { Size Classification }}$}} & \multicolumn{2}{|c|}{ Xenoliths / Autoliths } \\
\hline & & & & & & Content & Type \\
\hline $\begin{array}{l}>15 \% \\
<15 \%>1 \%\end{array}$ & $\begin{array}{l}\text { Macrocrystic } \\
\text { Sparsely } \\
\text { Macrocrystic } \\
\text { Phenocrystic }\end{array}$ & $\begin{array}{l}\text { Very coarse } \\
\text { Coarse } \\
\text { Medium } \\
\text { Fine } \\
\text { Very fine } \\
\text { Very very } \\
\text { fine }\end{array}$ & $\begin{array}{l}V C \\
C \\
M \\
F \\
V F \\
W F\end{array}$ & $\begin{array}{l}>10 \\
5-10 \\
2-5 \\
0.5-2 \\
0.2-0.5 \\
<0.2\end{array}$ & $\begin{array}{l}\mathrm{mm} \\
\mathrm{mm} \\
\mathrm{mm} \\
\mathrm{mm} \\
\mathrm{mm} \\
\mathrm{mm}\end{array}$ & $\begin{array}{c}>15 \% \\
+4 \mathrm{~mm} \text { Breccia }\end{array}$ & $\begin{array}{l}\text { Lithic-- Mantle } \\
\text { Autolithic } \\
\text { Exotic Xenocrystic } \\
\text { Heterolithic }\end{array}$ \\
\hline
\end{tabular}

FIGURE 1: Textural classification of kimberlites

\begin{tabular}{|c|c|c|c|c|c|}
\hline Pipe Zone & & & Textural interpretation & & Facies \\
\hline \multirow[t]{3}{*}{ CZ Crater Zone } & + & VK & Volcaniclastic kimberlite & $=$ & Crater-facies \\
\hline & + & PK & Pyroclastic kimberlite & $=$ & Crater-facies \\
\hline & + & RVK & Epiclastic kimberlite & $=$ & Crater-facies \\
\hline DZ Diatreme Zone & + & TK & Tuffisitic kimberlite breccia & $=$ & Diatreme- facies \\
\hline RZ Root Zone & + & HK & Hypabyssal kimberlite & $=$ & Hypabyssal-facies \\
\hline
\end{tabular}

FIGURE 2: Pipe zone and facies terminology of kimberlites 